\title{
Assessment of Fluoride Concentration in Groundwater in Kanchipuram, Tamil Nadu, India.
}

\author{
Pradeep kumar. ${ }^{1}$, SriPrakash.DKN ${ }^{2}$ \\ I(Reader, Public Health Dentistry, Saveetha Dental College/ Saveetha University, India) \\ ${ }^{2}$ (CRRI, Saveetha Dental College/ Saveetha University, India)
}

\begin{abstract}
Fluoride contamination of groundwater is a growing problem in many parts of the world. The present study is an attempt to assess fluoride concentration of groundwater in parts of Kanchipuram district, Tamil Nadu . It was found that fluoride concentration ranged from 0.05-1.04 $\mathrm{mg} / \mathrm{L}$. If residents consume non potable high fluoride water they may suffer from yellow, mottled teeth - dental fluorosis Therefore, it is essential to evolve regulations designated to improve the health and safety of the human and natural environment in the study area.
\end{abstract}

Keywords: Fluoride contamination, Groundwater, Kanchipuram

\section{Introduction}

Dyeing and printing of textile being a traditional industry of Kanchipuram town, a good number of textile industries along with dyeing and printing clusters have come up in the area. Water the Elixir of life is facing a severe threat due to pollution in Kancheepuram town which is located at a distance of $76 \mathrm{~km}$ from Chennai. The region is dependent on groundwater for drinking and irrigation purposes.

The processes followed in textile industries are spinning of fiber to yarn, sizing to improve stiffness, scouring and desizing to remove excess sizing materials, bleaching to remove pectin and wax from the yarn and fabric and colouring and printing to provide desired colour and design to the cloth. Dyeing is a combined process of bleaching and colouring, which generates voluminous quantities of wastewaters and in turn causes environmental degradation. The effluents consist of high concentrations of dye stuff, biochemical oxygen demand, total dissolved solids, sodium, chloride, fluoride, sulphate, heavy metals and carcinogenic dye ingredients [1].

Earlier studies by Kesavan and Parameswari (2005) revealed that the groundwater sources in Kanchipuram are not suitable for drinking purpose without proper treatment [2]. The problem of high fluoride concentration in groundwater resources has now become one of the most important toxicological and geoenvironmental issues in kanchipuram [3]. The present study was carried out to investigate the effect of dyeing industrial effluents on the quality of groundwater in and around the Kanchipuram town with reference its fluoride concentration.

\section{Materials And Methods}

Total of 13 groundwater samples (used for drinking purpose), from bore wells and dug wells, were collected in pre-cleaned plastic bottles from 9 selected areas of kanchipuram. About 500ml of water was collected in a clean dry polythene container and labeled with information like date of collection, source and place. Fluoride levels were analyzed by standardized analytical method by the Chief Water Analyst, State Level Water Testing Laboratory, Tamilnadu Water Supply And Drainage Board (TWAD), Government of Tamilnadu, Chennai (ISO 9001-2000 - certified).

\section{Results}

Table 1 shows the fluoride concentration in groundwater in various regions of kanchipuram collected between December 2013 and January 2014. It was found that fluoride concentration ranged from 0.05-1.04 $\mathrm{mg} / \mathrm{L}$.

Table 1 shows the fluoride concentration in groundwater in various sites of kanchipuram

\begin{tabular}{|c|c|c|c|}
\hline Sample No. & Site of collection & Source of water & Fluoride concentration $\mathbf{~ m g} / \mathbf{L}$ \\
\hline S1 & Chinna kanchipuram & Bore well & 0.88 \\
\hline S2 & Toll Gate & Open well & 0.55 \\
\hline S3 & Pulalur & Bore well & 0.98 \\
\hline S4 & Namunor & Borewell & 1.04 \\
\hline S5 & Kolivakkam & Open well & 1.03 \\
\hline S6 & Periya kanchipuram & Bore well & 0.36 \\
\hline S7 & Periya kanchipuram & Bore well & 0.05 \\
\hline
\end{tabular}




\begin{tabular}{|c|c|c|c|}
\hline S8 & Orikkai & Bore well & 0.20 \\
\hline S9 & Chinna kanchipuram & Bore well & 0.59 \\
\hline S10 & Toll gate & Bore well & 0.37 \\
\hline S11 & Selvulimedu & Bore well & 0.20 \\
\hline S12 & selvulimedu & Open well & 0.26 \\
\hline S13 & Pillarpallayam & Bore well & 0.26 \\
\hline
\end{tabular}

\section{Discussion}

The present study is an attempt to assess fluoride concentration of groundwater in parts of Kanchipuram district, Tamil Nadu. It was found that fluoride concentration ranged from 0.05-1.04 mg/L. In the study conducted by Dar MA et al (2009) in kanchipuram showed that fluoride abundance in the range of 1 to $3.24 \mathrm{mg} / \mathrm{L}$ [3] . Pradeep kumar et al (2011) showed ground water contamination of fluoride releases from fertilizer plants in Ennore showed fluoride concentration in the range of 0.98 to $1.04 \mathrm{mg} / \mathrm{L}$ which is similar to this present study[4]. In a similar study done by Balakrishnan. et al (2008) in kanchipuram showed ground water contamination of fluoride in the range of 0.13 to $1.09 \mathrm{mg} / \mathrm{L}[5]$.

\section{Conclusion}

If residents consume non potable high fluoride water they may suffer from yellow, mottled teeth dental fluorosis. Therefore, it is essential to evolve regulations designated to improve the health and safety of the human and natural environment in the study area.

\section{Acknowledgement}

We acknowledge the Chief Water Analyst, State Level Water Testing Laboratory, (Tamilnadu Water Supply And Drainage Board), Chennai, for estimating the chemical parameters required for this study.

\section{References}

[1]. Tchobanoglous G and Burton FL Wastewater engineering: treatment, disposal and reuse. Tata McGraw-Hill Publishing Co. Ltd, New Delhi.1995.

[2]. Kesavan KG and Parameswari R.Evaluation of groundwater quality in Kancheepuram. Indian J. Environ. Prot. 25(3), 2005, 235239.

[3]. Dar MA, Sankar K, Dar IA., Fluorine contamination in groundwater: a major challenge. Environ Monit Assess.173(1-4), 2011,95568.

[4]. Pradeep kumar, Joseph john. Fluoride contamination of ground water and its impact on dental health in Ennore,Chennai. Indian j of environ sci 15(2), 2011,127-130.

[5]. Balakrishnan.M, Arul Antony S, Gunasekaran S and Natarajan R.K. Impact of dyeing industrial effluents on the groundwater quality in Kancheepuram (India). Ind J of Sci and Tech. 1(7).2008, 1-8. 